\title{
MARKETING MIX DAN TINGKAT MARGIN DALAM PENGAMBILAN KEPUTUSAN PEMBIAYAAN PADA NASABAH BANK SYARIAH
}

\author{
Rusny Istiqomah Sujono ${ }^{1}$, Febrian Wahyu Wibowo ${ }^{2}$ \\ 1,2 Universitas Alma Ata Yogyakarta, Indonesia
}

$\triangle$ Corresponding Author:

Nama Penulis: Rusny Istiqomah Sujono

E-mail: rusny.istiqomah@uaa.ac.id

\section{Abstract}

The purpose of this study was to determine the effect of the marketing mix and margin levels on customer decisions. The design and methodology of this research is field research where the authors make observations to obtain the required data. Data is collected by giving questionnaires to customers who have several financial activities at the bank. The sample of this study was 100 respondents. The results showed that of the five Marketing mix variables, several variables significantly influenced customer interest, such as product, price, promotion, and margin level. However, place variables do not significantly influence customer decisions. Although not all marketing mix variables significantly influence customer interest, the marketing mix is still important for Islamic banks to attract customers.

Key Words: Marketing mix; Margin; Customer Decision

\section{Abstrak}

Tujuan Penelitian ini adalah untuk mengetahui pengaruh Marketing mix dan tingkat margin terhadap keputusan nasabah. Desain dan metodologi penelitian ini adalah penelitian lapangan dimana penulis melakukan observasi untuk memperoleh data yang dibutuhkan. Data dikumpulkan dengan memberikan kuesioner kepada pelanggan yang memiliki beberapa kegiatan keuangan di bank. Sampel penelitian ini berjumlah 100 responden. Hasil Penelitian menunjukkan bahwa dari lima variabel Marketing mix, ada beberapa variabel yang secara signifikan mempengaruhi minat pelanggan, seperti produk, harga, promosi, dan tingkat margin. Namun variabel tempat tidak berpengaruh signifikan terhadap keputusan nasabah. Meskipun tidak semua variabel marketing mix secara signifikan mempengaruhi minat pelanggan, Marketing mix tetap penting bagi bank syariah untuk menarik pelanggan.

Kata Kunci : Marketing mix; Tingkat Margin; Keputusan Nasabah

\section{PENDAHULUAN}

Persaingan bisnis pada era globalisasi sekarang ini menjadi lebih ketat, hal ini disebabkan oleh semakin meningkatnya jumlah lembaga-lembaga 
keuangan yang terus berkembang. Lembaga keuangan merupakan jantung perekonomian suatu negara, karena peran dan fungsinya yang sangat penting yang sangat berpengaruh terhadap perekonomian suatu negara oleh karena itu sangat penting keberadaannya dalam suatu negara. Adanya UU no. 07 thn. 1992 tentang perbankan yang dapat menjalankan usahanya dalam dua sistem yakni secara konvensional dan syariah (Sumitro, 2002).

Perusahaan perbankan di Indonesia berlomba-lomba untuk semakin meningkatkan kualitas banknya baik dalam segi banyaknya nasabah, produk yang diberikan kepada nasabah. Semua itu bertujuan untuk meningkatkan perbankan itu sendiri ditengah banyaknya persaingan didunia perbankan baik konvensional maupun syariah. Sehingga, salah satu cara yang dilakukan oleh perbankan di Indonesia adalah dengan meningkatkan operasional terutama pada bagian marketing.

Marketing salah satu hal yang sangat penting untuk keberlajutan perusahaan serta agar terus meningkatkan profitabilitas perusahaan (Akgun, Ali Ekber dkk, 2014). Pada bagian marketing, perbankan sering menggunakan beberapa aspek yang tergabung pada Marketing mix perbankan syariah. Dalam marketing terdapat unsur seperti produk, promosi, harga, tempat, orang, proses, dan physical evidence yang kesemua unsur tersebut mempengaruhi keputusan konsumen terhadap suatu perusahaan, dalam hal ini perbankan syariah.

Bank syariah merupakan lembaga keuangan yang operasional produknya dikembangkan berlandaskan pada Al-Quran dan Hadits Nabi SAW (Muhammad, 2011). Bank syariah adalah sebagai satu solusi terkait permasalahkan kehalalan bunga bank atau yang diartikan riba. Riba pada umumnya yaitu menetapkan bunga pinjaman atau melebihkan jumlah pinjaman pokok. Menurut pendapat para ulama riba hukumnya haram. Salah satu ulama yaitu Yusuf Qaradhawi berpendapat bahwa bunga yang berlaku saat ini umumnya adalah haram. Namun dalam praktiknya di perbankan konvensional terdapat praktik - praktik yang dilarang dalam Islam, seperti di dalamnya terdapat pembiayaan-pembiayaan barang haram, transaksi yang tidak sesuai dengan syariat Islam dan lain-lain. Oleh karena hal tersebut hadirlah bank syariah yang mengelola keuangan dengan berlandaskan prinsip-prinsip Islam.

Marketing mix digunakan oleh pihak marketing untuk menawarkan produknya agar dapat memasuki pasar sasaran atau target penjualan. Selain itu Marketing mix juga merupakan elemen yang sangat membantu perusahaan dalam mengatahui faktor-faktor yang dicari konsumen dalam produk yang dikeluarkan perusahaan (Wahab dkk, 2016). Marketing mix adalah salah satu faktor penting dalam pengambilan keputusan dan evaluasi yang berkaitan dengan pasar perusahaan sehingga Marketing mix atau 
strategi pemasaran merupakan kombinasi dari elemen-elemen penting untuk perencanaan dan pemenuhan seluruh proses operasi pemasaran (Aghaei dkk, 2014).

Produk merupakan salah satu item Marketing mix yang terdiri dari komponen keragaman produk, kualitas, design, ciri, nama merek, kemasan, ukuran, pelayanan, garansi dan imbalan (Abril dkk, 2016). Harga dalam produk perbankan syariah terdiri dari tingkat penawaran dari nisbah bagi hasil, margin murabahah dan fee ijarah, serta fee based income rates. Harga pada sisi pendanaan mencakup produk-produk giro, tabungan dan deposito. Sedangkan pada sisi pembiayaan mencakup produk pembiayaan berbasis jual-beli, sewa, jasa dan investasi. Promosi, terdiri dari promosi penjualan, periklanan, tenaga penjualan, public relation, dan pemasaran langsung. Tempat, terdiri dari saluran pemasaran, cakupan pasar, pengelompokan, lokasi, persediaan dan transportasi (Laksana, 2008).

Perilaku konsumen juga mempertimbangkan jenis produk yang akan dikonsumsi. Apabila produk yang ditawarkan dianggap sebagai produk yang terlalu rumit, maka informasi yang diterima oleh calon nasabah akan terhambat. Sebaliknya apabila produk mempunyai keistimewaan keunggulan mudah dilihat, dibayangkan atau dijelaskan kepada konsumen, maka mereka akan lebih mudah mengadopsinya (Prasetijo, 2005). Dampak selanjutnya hal ini juga akan berpengaruh terhadap loyalitas dari konsumen (Sya'idah dan Tontowi, 2018). Selain itu juga terdapat salah satu faktor lagi yang menjadi persaingan untuk menarik konsumen di dunia perbankan yaitu besaran tingkat margin. Tingkat margin merupakan salah satu faktor yang di utamakan oleh konsumen, karena setiap nasabah yang bergabung dengan suatu bank tentunya mengharapkan keuntungan akan dana yang mereka investasikan dalam suatu bank. Sistem bagi hasil adalah sistem yang memiliki tata cara tersendiri dalam membagi hasil usaha antara pemilik modal dengan pengelola dana (mudharib). Pembagian hasil usaha ini dapat terjadi antara bank sebagai penyimpan dana, maupun antara bank dengan nasabah penerima dana. Besaran tingkat margin yang ditawarkan kepada konsumen berbeda beda antara bank yang satu dengan yang lainnya. Dalam penelitian ini hal tersebut yang akan diteliti apakah perbedaan besaran tingkat margin yang ditawarkan oleh suatu bank berpengaruh signifikan terhadap keputusan dari para konsumen tersebut ataukan hal tersebut bukanlah faktor utama yang menjadikan ketertarikan suatu konsumen terhadap suatu bank syariah. Oleh karenanya tingkat margin yang dijanjkan oleh bank kepada nasabah merupakan salah satu aspek terpenting bagi nasabah sebagai pertimbangan untuk melakukan pembiayaan pada suatu lembaga perbankan syariah. 
Pertumbuhan perbankan syariah sudah menunjukkan kenaikan namun belum sebesar dan secepat bank konvensional oleh karenanya aspek-aspek yang terkandung dalam Marketing mix belumlah berjalan secara maksimal, karena banyak masyarakat di Indonesia khususnya yang belum sepenuhnya memahami dan mengerti mengenai bank syariah itu sendiri dan juga sumber daya manusia yang bekerja dalam bank syariah bukanlah sumber daya manusia yang berlatar belakang syariah. Selain itu juga tingkat margin yang dianggap oleh masyarakat tidak sebesar tingkat bunga di bank konvensional, hal ini yang menjadikan masyarakat kurang tertarik pada bank syariah itu sendiri. Namun apakah hal ini memang sangat berpengaruh bagi masyarakat di Indonesia ataukah tidak,oleh karenanya pada penelitian kali ini saya mengangkat judul "Pengaruh Marketing mix dan Tingkat Margin Terhadap Keputusan Nasabah Pembiayaan Pada Bank Syariah". Variabel Marketing mix dalam penelitian ini yaitu berupa produk, harga, tempat, dan promosi. Penelitian ini penting dilakukan karena persaingan bank syariah semakin ketat dan hasil penelitian diharapkan dapat memberikan kontribusi bagi bank syariah dalam merancang Marketing mix dan tingkat margin yang maksimal.

\section{KAJIAN PUSTAKA}

Wahab (2012) dalam penelitiannya mengatakan bahwa Marketing mix tidak berpengaruh siginifikan terhadap keputusan konsumen untuk menjadi nasabah Bank Syariah sedangkan faktor religius berpengaruh signifikan terhadap keputusan konsumen untuk menjadi nasabah Bank Syariah. Religi dalam pemasaran produk juga sangat berpengaruh dalam perkembangannya (Yeu dkk, 2012). Produk dalam suatu bank syariah menjadi salah satu acuan konsumen untuk melakukan pembiayaan atau menjadi nasabah dalam suatu bank syariah (Mu'arif, 2013). Hal yang menjadi sangat penting juga dalam variabel pemasaran yang sangat berpengaruh pada permintaan atau minat konsumen adalah harga dan iklan (Mesak dkk, 2020). Selain produk yang dapat menarik minat konsumen, besaran margin bagi hasil yang ditawarkan juga menjadi hal terpenting untuk menarik minat pasar menjadi nasabah dalam suatu bank syariah (Joharudin, 2007). Hal tersebut didasari pada minat masyarakat di Indonesia khusunya yang sangat mengacu pada besaran keuntungan yang didapat pada suatu instrumen keuangan. Ketika pelaksanaan skema bagi hasil berjalan dengan baik dan dengan memberikan margin sesuai dengan harapan nasabah maka akan menambah nasabah baru yang ingin bergabung dan bermitra pada bank syariah (Margono, 2013). Pada penelitian khasanah dan gunawan (2014) membuktikan bahwa tingkat margin bagi hasil berpengaruh positif dan memiliki pengaruh yang kuat untuk menarik minat nasabah melakukan pembiayaan pada bank syariah. 
Namun dalam penelitian lain juga mendukung hal ini, di antaranya Hogreveet dkk (2017) yang mengatakan bahwa salah satu faktor yang menarik konsumen adalah adanya tingkat margin yang berkelanjutan dan penelitian Aini (2015) yang mengatakan bahwa tingkat margin berpengaruh positif dan signifikan dalam pengambilan keputusan nasabah pembiayaan murabahah di BMT.

Perbedaan dalam penelitian ini dengan penelitian-penelitian yang telah ada yaitu variabel yang diteliti dalam penelitian ini berbeda dengan penelitian sebelumnya yaitu adanya variabel tingkat margin, model penelitian, serta lokasi dan waktu penelitian yang berbeda.

\section{Marketing mix}

Marketing mix menurut bahasa adalah Marketing mix, sedangkan dalam istilah Marketing mix ialah strategi pemasaran yang dilaksanakan secara satu kesatuan atau strategi pemasaran yang dilakukan secara bersamaan dalam menerapkan elemen - elemen dan strategi yang ada dalam Marketing mix itu sendiri, Marketing mix sering juga dianggap perangkat alat pemasaran taktis yang dapat dikendalikan, produk, harga, distribusi, dan promosi yang dipadukan oleh perusahaan untuk menghasilkan respon yang diinginkan dalam pasar yang beroperasi paling efisien (Isoraite, 2016) sehingga dapat memenuhi tujuan dari Individu atau suatu perusahaan (Lusch, 2007) dalam Pomering. (Kotler dan Amstrong, 2008) Pemasar menggunakan Marketing mix agar produk yang dijual dapat memasuki pasar sasaran atau target pasar. Item Marketing mix meliputi produk yaitu terdiri dari komponen keragaman produk, kualitas, design, ciri, nama merek, kemasan, ukuran, pelayanan, garansi dan imbalan. Harga, terdiri dari daftar harga, diskon, potongan harga khusus, periode pembayaran dan syarat kredit. Promosi, terdiri dari promosi penjualan, periklanan, tenaga penjualan, public relation, dan pemasaran langsung. Tempat, terdiri dari saluran pemasaran, cakupan pasar, pengelompokan, lokasi, persediaan dan transportasi (Laksana, 2008:13). Dengan adanya komunikasi yang baik antara marketing perusahaan dengan nasabah terhadap pengenalan produk bank akan meningkatkan minat nasabah terhadap produk bank (Syahputra, 2019).

\section{Tingkat Margin}

Dalam Islam Rasulullah SAW mengajarkan bahwa berilah upah kepada pekerja sebelum keringatnya mengering, dalam hal ini rasululah mengajarkan segera adanya pembagian hasil atas kerja yang telah dilakukan seseorang, selain itu juga dalam Islam melarang melakukan kecurangan atas pembagian hasil usaha antara satu orang dengan yang lainnya. Perbankan syariah pun harus melakukan pembagian hasil kepada nasabahnya dengan 
cara yang baik tanpa ada salah satu pihak yang dirugikan dan harus saling mengetahui satu sama lain mengenai berapa besaran tingkat margin yang akan diberikan, sehingga tidak terdapat kecurangan dikemudian hari.

\section{Keputusan Nasabah}

Pengambilan keputusan sangat berkaitan dengan perilaku konsumen yang dilakukan dalam mengambil keputusan tersebut, jadi dalam memilih keputusan kita harus melihat perilaku-perilaku konsumen yang ada didalam masyarakat luas.

Faktor - faktor yang mempengaruhi konsumen dalam mengambil keputusan adalah (A.A Anwar Prabu Mangkunegara, 2012):

\section{Kekuatan Sosial Budaya}

a. Faktor Budaya, Budaya adalah sebagai hasil kreativitas manusia dari satu generasi ke generasi berikutnya yang sangat menentukan bentuk perilaku dalam kehidupannya sebagai anggota masyarakat. Kebudayaan meliputi ilmu pengetahuan, kepercayaan, seni, moral, adat, kebiasaan, dan normanorma yang berlaku pada masyarakat.

b. Faktor Kelas Sosial, Kelas sosial dinilai dari kedudukan seseorang di dalam masyarakat. Kelas sosial berbeda dengan status sosial merupakan dua konsep yang berbeda.

c. Faktor Kelompok Anutan (Small Reference Group), Kelompok anutan yaitu suatu kelompok orang yang dapat mempengaruhi sikap, pendapat, norma, dan perilaku konsumen yang dimana hal ini dapat mempengaruhi perilaku konsumen.

d. Faktor Keluarga, Keluarga merupakan faktor awal pembentuk karakter dan perilaku seseorang.

\section{Kekuatan Faktor Psikologis}

a. Faktor Pengalaman Belajar, Adanya perubahan sifat atau perilaku dari permasalahan sebelumnya adalah hasil dari pembelajaran. Hal ini tentunya akan mempengaruhi perilaku konsumen yang tentunya kemudian berpengaruh keputusan pada konsumen.

b. Faktor kepribadian, Bentuk dari sifat-sifat atau kepribadian dari individu sangat berpengaruh pada pembentukan sebuah karakter atau perilaku individu tersebut. Kepribadian suatu individu tentunya terbentuk atau dipengaruhi oleh faktor internal dan faktor ekternal atau lingkungan dari individu tersebut.

c. Faktor sikap dan keyakinan, Sikap adalah salah satu bentuk kesiapan seseorang dalam menghadapi sesuatu. Keyakinan dapat dipengaruhi oleh sikap. Komunikasi merupakan salah satu faktor yang dapat mengubah sifat dan keyakinan dari individu (Sefudin, 2014). 
d.Konsep diri (Self-Concept), Cara pandang terhadap sesuatu dan pengendalian diri membentuk pengembangan diri yang disebut dengan konsep diri. Konsep diri berpengaruh terhadap apa yang akan kita lakukan ke depannya.

\section{METODE}

Jenis penelitian ini termasuk penelitian lapangan yaitu penelitian yang dilakukan di lapangan untuk mencari lebih dalam dan meneliti data yang terkait dengan faktor-faktor yang mempengaruhi keputusan nasabah untuk melakukan pembiayaan pada bank syariah (studi kasus BSM).

Pengumpulan data dalam penelitian ini menggunakan kuisioner yang telah diedarkan kepada sampel peneliti. Penelitian ini bersifat kuantitatif, yang menggunakan data numerik dari variabel yang diteliti (Sugiyono, 2011). Penelitian ini dilakukan disalah satu cabang Bank Syariah Mandiri yang terletak di Jalan Solo, Yogyakarta. Penelitian ini menggunakan data primer. Dalam penelitian ini data diperoleh dari hasil wawancara dan kuisioner yang dibagikan kepada para nasabah.

Populasinya adalah seluruh nasabah pembiayaan. Dalam pengambilan sampel akan terfokus pada nasabah pembiayaan mudhorobah yang juga termasuk dalam nasabah pembiayaan. Jumlah ukuran sampel yang diambil dari populasi menggunakan rumus yang dikemukan oleh Slovin (Wijoyo, 2011). Berdasarkan perhitungan menggunakan metode Slovin maka sampel dalam penelitian ini adalah 100,3745 dibulatkan menjadi 100 responden.

Metode analisis yang dilakukan peneliti dalam penelitian ini adalah dengan cara menentukan data, mengumpulkan data dan menginterpretasikan data yang diakhir penelitian dapat menghasilkan berupa gambaran masalah yang dihadapi. Kuisioner penelitian ini terbagi menjadi dua bagian : bagian pertama mengenai karakteristik responden, dan bagian ke dua yaitu mengenai pernyataan responden tentang variabel dalam penelitian: Marketing mix dan tingkat margin. Untuk setiap jawaban diberikan skor dengan menggunakan skala likert. Pengisisan kuisioner disusun dalam bentuk kalimat pernyataan. Untuk mendapatkan hasil penelitian yang valid dan reliable, maka perlu dilakukan uji validitas dan reliabilitas terhadap variabel atribut.

\section{HASIL DAN PEMBAHASAN}

\section{Analisis Regresi Linier Berganda}

Analisis ini digunakan untuk mengetahui pengaruh atau hubungan variabel bebas yang di dalam penelitian ini berupa produk, harga, promosi, tempat, orang, proses, bukti fisik, bagi hasil. Variabel terikat berupa keputusan nasabah. Tabel 1. menunjukkan hasil output olah data yaitu 
sebagai berikut. Berdasarkan hasil pengolahan data pada Tabel 1 kolom Unstandardize Coefficients bagian B diperoleh persamaan linier berganda sebagai berikut :

$$
Y=-6,237+0,227 X 1-0,632 X 2+0,226 X 3+0,135 X 4+0,234 X 5
$$

Tabel 1. Hasil Uji Analisis Regresi Linier Berganda

\begin{tabular}{ccc}
\hline Model & $\begin{array}{c}\text { Unstandardized } \\
\text { B }\end{array}$ & Signifikan \\
\hline (Constant) & -6.237 & .002 \\
Produk & .227 & .004 \\
Harga & -.632 & .000 \\
Promosi & .226 & .020 \\
Tempat & .135 & .118 \\
Tingkat Margin & .234 & .003 \\
\hline
\end{tabular}

Sumber : Data diolah, 2019

\section{Pengujian Hipotesis}

Pengujian hipotesis yang menyatakan ada pengaruh secara simultan produk, harga, promosi, tempat, orang, proses, bukti fisik, dan tingkat margin terhadap keputusan nasabah melakukan pembiayaan dapat dilihat dari hasil uji F berikut ini.

Berdasarkan Tabel 2 diketahui bahwa nilai signifikansi sebesar 0,000< 0,05 sehingga dapat disimpulkan bahwa produk, harga, promosi, tempat, orang, proses, bukti fisik, dan tingkat margin secara bersama-sama (simultan) berpengaruh signifikan terhadap keputusan nasabah untuk melakukan pembiayaan pada PT BSM cabang Yogyakarta.

Tabel 2. Hasil Uji F

\begin{tabular}{cc}
\hline Model & Sig. \\
\hline Sumber : Data diolah, 2019 & 0,000 \\
\end{tabular}

Pengujian hipotesis yang menyatakan ada pengaruh secara parsial terhadap keputusan nasabah dapat dilihat dari hasil uji t pada Tabel 3 berikut ini.

Tabel 3. Hasil Uji t

\begin{tabular}{cl}
\hline Model & Sig. \\
\hline (Constant) & .002 \\
Produk & .004 \\
Harga & .000 \\
Promosi & .020 \\
Tempat & .118 \\
Tingkat margin & .003 \\
\hline
\end{tabular}


Apabila nilai signifikansi variabel lebih kecil dari taraf signifikan 0,05 , atau nilai sig. < 0,05 maka H1 diterima dan H0 ditolak. Sebaliknya apabila nilai signifikan variabel lebih besar dari taraf signifikan 0,05 atau nilai sig. > 0,05, maka H1 ditolak dan H0 diterima. Variabel yang secara signifikan mempengaruhi keputusan nasabah antara lain produk, harga, promosi, dan tingkat margin. Sedangkan variabel tempat tidak signifikan mempengaruhi keputusan nasabah.

\section{Uji Determinasi $\left(\mathbf{R}^{2}\right)$}

Uji determinasi bertujuan untuk mengetahui seberapa besar kemampuan variabel bebas menjelaskan cariabel terikat. Nilai R square dikatakan baik jika diatas 0,5 .

Tabel 4. Pengujian Koefisien Determinasi

\begin{tabular}{ccccc}
\hline Model & $\mathbf{R}$ & $\begin{array}{c}\mathbf{R} \\
\text { Square }\end{array}$ & $\begin{array}{c}\text { Adjusted } \\
\text { R Square }\end{array}$ & $\begin{array}{c}\text { Std. Error of } \\
\text { the Estimate }\end{array}$ \\
\hline 1 & $.795^{\mathrm{a}}$ & .632 & .600 & 1.79463 \\
\hline
\end{tabular}

Sumber : Data diolah (2019)

Nilai R square yang ditunjukkan pada Tabel 4 sebesar 0,632, artinya sebesar 63,2\% veriabel terikat (keputusan nasabah) dijelaskan oleh variabel bebas (produk, harga, promosi, tempat, orang, proses, bukti fisik, dan tingkat margin) dan sisanya sebebsar 36,8\% dijelaskan oleh faktor-faktor lain yang tidak diikutkan dalam penelitian ini.

Hasil Penelitian ini menunjukkan bahwa Marketing mix dan Tingkat Margin memiliki pengaruh terhadap Keputusan Nasabah.

\section{Pengaruh produk terhadap keputusan nasabah.}

Dalam strategi Marketing mix, yang perlu diperhatikan pertama kali adalah produk. Hal ini penting karena tanpa adanya produk, strategi Marketing mix lainnya tidak dapat dilakukan. Produk merupakan sesuatu yang dapat ditawarkan ke suatu pasar untuk memenuhi keinginan atau kebutuhan (Winardi, 1989). Selain itu produk juga merupakan identitas suatu perusahaan dan alasan seorang konsumen memilih suatu produk sesuai kebutuhannya. Baik buruknya suatu produk sangat berpengaruh pada kelangsungan hidup suatu perusahaan. Berdasarkan hasil pengujian secara statistik menggunakan regresi berganda secara parsial pengaruh produk terhadap keputusan nasabah diperoleh nilai sig 0,004 < 0,05, maka H1 diterima dan HO ditolak. Variabel produk berpengaruh positif signifikan terhadap keputusan nasabah. Dapat dikatakan bahwa produk yang dimiliki oleh Bank Syariah Mandiri merupakan produk yang menguntungkan nasabah, sesuai dengan keinginan nasabah, menarik nasabah untuk 
melakukan pembiayaan dan mempunyai beragam produk yang di butuhkan oleh nasabah. Artinya variabel produk berpengaruh positif dan signifikan terhadap keputusan nasabah. Hal ini sama dengan penelitian sebelumnya yang disusun oleh joharudin yang berjudul "Strategi Bank Syariah Mandiri Cik Ditiro Dalam Meningkatkan Kepuasan Nasabah (metode Marketing mix) yang menyatakan bahwa produk berpengaruh signifikan terhadap minat nasabah.

\section{Pengaruh harga terhadap keputusan nasabah.}

Harga merupakan salah satu hal yang penting bagi konsumen. mahal atau murahnya suatu harga sangat menentukan minat konsumen untuk membeli suatu produk. Harga erat kaitannya dengan produk, mahal atau murahnya suatu harga di tentukan dengan kualitas suatu produk atau jasa. Berdasarkan hasil pengujian secara statistik menggunakan regresi berganda secara parsial pengaruh harga terhadap keputusan nasabah diperoleh nilai sig 0,000<0,05, maka H1 diterima dan H0 ditolak. Variabel harga berpengaruh positif signifikan terhadap keputusan nasabah. Dapat dikatakan bahwa harga yang ada tidak sesuai dengan kebutuhan nasabah, rincian harga yang diberikan kepada nasabah jelas, dan cicilan bulanan yang ditanggung nasabah ringan. Artinya variabel harga berpengaruh positif dan signifikan terhadap keputusan nasabah, karena ketika harga menurun permintaan oleh nasabah meningkat dan ketika harga naik maka permintaan dari nasabah akan menurun.

Bagi perbankan terutama bank yang berdasarkan prinsip konvensional, harga adalah bunga, biaya administrasi, biaya provinsi dan komisi, biaya kirim, biaya tagih, biaya sewa, biaya iuran dan biaya-biaya lainnya (Kasmir, 2005). Harga dalam produk perbankan syariah meliputi tingkat penawaran atas nisbah tingkat margin, margin murabahah dan fee ijarah, serta fee based income rates. Pricing pada sisi pendanaan mencakup produk-produk giro, tabungan dan deposito. Sedangkan pada sisi pembiayaan mencakup produk pembiayaan berbasis jual-beli, sewa, jasa dan investasi.

Hal ini mendukung penelitian sebelumnya yang disusun oleh Joharudin yang berjudul "Strategi Bank Syariah Mandiri Cik Ditiro Dalam Meningkatkan Kepuasan Nasabah (metode Marketing mix)" yang menyatakan bahwa harga berpengaruh positif secara signifikan terhadap minat nasabah.

\section{Pengaruh promosi terhadap keputusan nasabah}

Unsur promosi dalam Marketing mix jasa membentuk peranan penting dalam membantu mengkomunikasikan positioning jasa kepada para pelanggan dan pasar-pasar relationship. Promosi merupakan alat yang dapat digunakan organisasi jasa untuk ekskomunikasi dengan pasar sasarannya 
(Payne, 2000). Di dalam bauran komunikasi ada berbagai macam alat komunikasi alternatif yang dapat dipergunakan dalam suatu program komunikasi.Berdasarkan hasil pengujian secara statistik menggunakan regresi bergandasecara parsial pengaruh promosi terhadap keputusan nasabah diperoleh nilai sig 0,020<0,05, maka H1 diterima dan H0 ditolak. Variabel promosi berpengaruh positif signifikan terhadap keputusan nasabah. Dapat dikatakan bahwa iklan yang dilakukan Bank Syariah Mandiri menarik minat nasabah, bank sering melakukan undian berhadiah yang menarik minat nasabah, bank melakukan pendekatan kepada nasabah dengan memberikan brosur, dan bank menawarkan secara langsung kepada nasabah. Artinya variabel promosi berpengaruh positif dan signifikan terhadap keputusan nasabah. Hal ini sama dengan penelitian sebelumnya yang disusun oleh joharudin yang berjudul "Strategi Bank Syariah Mandiri Cik Ditiro Dalam Meningkatkan Kepuasan Nasabah (metode Marketing mix)" yang menyatakan bahwa promosi berpengaruh signifikan terhadap minat nasabah.

\section{Pengaruh tempat terhadap keputusan nasabah}

Strategisnya suatu lokasi suatu usaha merupakan elemen yang perlu di pikirkan matang-matang. Konsumen akan cenderung memilih lokasi yang mudah dituju. Terutama bagi lembaga keuangan dimana core business adalah jasa yang menuntut sering berinteraksi dengan konsumen baik di dalam dan di luar kantor. Oleh karena itu faktor lokasi menjadi sangat penting bagi perusahaan jasa lembaga keuangan. Strategisnya lokasi berdirinya lembaga keuangan akan sangat menentukan keberlangsungan bisnis jasa yang dijalani lembaga keuangan tersebut. Berdasarkan hasil pengujian secara statistik menggunakan regresi berganda secara parsial pengaruh tempat terhadap keputusan nasabah diperoleh nilai sig 0,118 > 0,05, maka H1 ditolak dan H0 diterima. Variabel tempat tidak berpengaruh signifikan terhadap keputusan nasabah. Dapat dikatakan bahwa lokasi tidak mudah dijangkau, kurang strategis, dan layanan atm yang sulit dijangkau. Artinya variabel tempat tidak berpengaruh terhadap keputusan nasabah. Hal ini berbeda dengan penelitian sebelumnya yang disusun oleh nailuss'adah yang berjudul "Pengaruh Marketing mix Terhadap Minat Menjadi Nasabah" menyatakan bahwa tempat berpengaruh posistif terhadap minat nasabah.

Tempat merupakan salah satu unsur dalam Marketing mix yang memegang peranan penting dalam hal melokasikan barang dan melancarkan arus barang dari produsen kekonsumen (Sofjan, 2000). Pelokasian barang dari produsen sampai ke konsumen akhir tidaklah mudah untuk dilakukan tanpa adanya saluran lokasi yang memadai. Apalagi untuk menjangkau suatu pasar yang luas, dalam hal ini membutuhkan berbagai macam perantara atau 
Rusny Istiqomah Sujono: Pengaruh Marketing Mix dan Tingkat Margin

saluran lokasi yang dapat menyampaikan barang sampai ketangan konsumen.

\section{Pengaruh margin terhadap keputusan nasabah}

Tingkat margin merupakan hal yang sering menjadi perhatian masyarakat, nasabah pembiayaan tentunya akan memilih pembagian hasil yang sesuai dengan keinginannya. Berdasarkan hasil pengujian secara statistik menggunakan regresi bergandasecara parsial pengaruh margin terhadap keputusan nasabah diperoleh nilai sig 0,003 < 0,05, maka H1 diterima dan H0 ditolak. Variabel margin berpengaruh positif signifikan terhadap keputusan nasabah. Dapat dikatakan bahwa margin sesuai dengan syariah, margin yang ditawarkan kompetitif, porsi margin menguntungkan nasabah, dan margin yang diberikan lebih besar dibandingkan bank syariah lain. Artinya variabel margin berpengaruh positif dan signifikan terhadap keputusan nasabah. Hal ini sama dengan penelitian sebelumnya yang disusun oleh Slamet Margono (2010) yang berjudul "Pelaksanaan Sistem Bagi Hasil Perbankan Syariah" menyatakan bahwa bagi hasil berpengaruh posistif terhadap minat nasabah, serta Penelitian dari Safitri (2012) yang mengatakan bahwa variabel tingkat margin memiliki pengaruh yang sangat tinggi terhadap keputusan Nasabah.

\section{KESIMPULAN}

Berdasarkan hasil analisis yang telah diperoleh, maka penulis dapat mengambil beberapa kesimpulan sebagai berikut. Variabel produk menunjukkan pengaruh positif dan signifikan terhadap keputusan nasabah melakukan pembiayaan. Variabel harga menunjukkan pengaruh positif dan signifikan terhadap keputusan nasabah melakukan pembiayaan. Menurut nasabah harga yang diberikan dari pihak bank relevan dan sesuai dengan kemampuan nasabah. Variabel promosi menunjukkan pengaruh positif dan signifikan terhadap keputusan nasabah melakukan pembiayaan. Bank sudah melakukan promosi dengan baik kepada nasabah dengan berbagai strategi yang dilakukan PT. BSM cabang Yogyakarta. Variabel tempat menunjukkan pengaruh positif dan tidak signifikan terhadap keputusan nasabah melakukan pembiayaan. Nasabah menuturkan lokasi bank yang ada di Yogyakarta sudah terletak di tempat-tempat strategis sehingga tidak terlalu mempengaruhi nasabah melakukan pembiayaan. Variabel margin menunjukkan pengaruh positif dan signifikan terhadap keputusan nasabah melakukan pembiayaan. Margin yang terapkan PT. BSM cabang Yogyakarta sesuai dengan syariah dan sesuai dengan keinginan nasabah. Berdasarkan hasil penelitian ini, penulis juga memberikan saran atau masukan Dari kedelapan variabel terdapat variabel tempat, orang, dan bukti fisik yang tidak 
signifikan terhadap keputusan nasabah melakukan pembiayaan. Sehingga diharapkan kelima variabel dapat dipertahankan dan dapat meningkatkan jumlah nasabah untuk melakukan pembiayaan pada PT. BSM cabang Yogyakarta. Selanjutnya perusahaan juga sebaiknya melakukan evaluasi terhadap variabel yang tidak signifikan agar kedepannya perusahaan akan semakin baik karena kesemua elemen Marketing mixnya berpengaruh terhadap keputusan nasabah.

\section{DAFTAR PUSTAKA}

Abril, Carmen, Belen Rodriguez Canovas. (2016). Marketing mix Effects on Private Labels brand equity. European Journal of Management and Business Economics 25. 168-175.

Aghaei, Mohammad, Elham Vahedi, Mohammad Safari Kahreg, Mahdi Pirooz. (2014). An examination of relationship between Services Marketing mix and Brand Equity Dimensions. Procedia Social and Behavioral Sciences 109. 865-869.

Aini, Aisyah Nur. (2015). Pengaruh Tingkat Margin terhadap Keputusan Pengambilan Pembiayaan Murabahah di BMT UGT Sidogiri Cabang Waru Sidoarjo. El-Qist Vol. 05 No. 1 April 2015

Akgun, Ali Ekber, Halit Keskin, Hayat Ayar C. (2014). Standardization and Adaptation of International Marketing mix Activities : A Case Study. Social and Behavioral Sciences. 609-618.

Arikunto, Suharsimi. (2006). Prosedur Penelitian, Cetakan XIII, Jakarta : Rineka Cipta.

Asnawi dan Masyhuri. (2011). Metodologi Riset Manajemen Pemasaran. Malang: UIN Malik Press.

Ghazali, Imam. (2009). Aplikasi Analisis Multivariate dengan Program SPSS. Cetakan IV. Semarang: Badan Penerbit UNDIP.

Hadi, Syamsul. (2006). Metodologi Penelitian Kuantitatif, Ekonisia. Yogyakarta: FE UII.

Hogreve, Jens, Anja Iseke, Klaus Derfuss and Tönnjes Eller. (2017). The Service-Profit Chain: A Meta-Analytic Test of a Comprehensive Theoretical Framework. Journal of Marketing. 81 Mei, 41-61.

Hurriyati, Ratih. (2005). Marketing mix dan Loyalitas Konsumen. Bandung: Alfabeta.

Isoraite, Margarita. (2016). Marketing mix Theoretical Aspects. International Journal of Research Granthaalayah. Vol. 4, June 2016. ISSN-2350-053.

Joharuddin,I. (2007). Strategi Bank Syariah Cik Di Tiro Yogyakarta Dalam Meningkatkan Kepuasan Nasabah(Analisis Marketig Mix), Tesis Program Studi Hukum Islam UIN Sunan Kalijaga, Yogyakarta.

Kasmir. (2002). Dasar-Dasar Perbankan, Jakarta; PT. Raja Grafindo Persada. Kasmir. (2005). Pemasaran Bank. Jakarta: Prenada Media.

Kotler dan Amstrong. (2008). Prinsip-Prinsip Pemasaran, jilid 1 ed VIII, Jakarta: Erlangga. 
Margono,Slamet. (2010). Pelaksanaan Sistem Bagi Hasil Bank Syariah (Tinjauan Umum Pada PT. Bank BTN Syariah Cabang Semarang). Tesis program Magister Ilmu Hukum Universitas Diponegoro. Semarang.

Mesak, Hani I, Abdullaahel Bari, T. Selwyn Ellis. (2020). Optimal dynamic marketing-mix policies for frequently purchased products and services versus consumer durable goods : A generalized analytic approach. European Journal of Operational Research. 764-777.

Mu'arif, Mahfudz. (2013). Pengaruh Marketing mix Terhadap Keputusan Nasabah Bank Syariah dan Konventional. Jurnal Manajemen dan Akuntansi Volume 4, Malang.

Muhammad. (2005). Manajemen Bank Syariah, edisi revisi, Yogyakarta: (UPP) AMP YKPN.

Nailusa'adah. (2011). Pengaruh Marketing mix Terhadap Keputusan Konsumen Menjadi Nasabah Bank BNI Syariah. Skripsi Fakultas Syariah dan Hukum UIN Syarif Hidayatullah. Boyolali.

Oesman, Yevin Marty. (2010). Sukses Mengelola Marketing mix, CRM, Customer Value, dan Customer Dependency. Bandung: Alfabeta.

Payne, Adrian. (2000). The Essense od service Marketing (Pemasaran Jasa). Diterjemahkan oleh: Fandy Tjiptono. Yogyakarta: ANDI.

Pomering, Alan. (2017). Marketing for sustainnability : Extending the conceptualisation of the Marketing mix to drive value for individuals and society at large. Australian Marketing Journal 25. 157-165.

Rangkuti, Freddy. (2011). Riset Pemasaran, Cetakan. X. Jakarta: PT. Gramedia Pustaka Utama.

Safitri, Enneng Nisa Alfiani (2019). Pengaruh Tingkat Margin dan Pelayanan Terhadap Kepuasan Nasabah pada Pembiayaan Murabahah di BPRS Metro. Finansia Volume 2 Nomer 2 Juli-Desember.

Sefudin, Akhmad. (2014). Redefinisi Marketing mix (Marketing mix) Studi Kasus Pada Universitas Indraprasta PGRI. Journal of Applied Business and Economics. Volume 1 Nomer 1.

Sugiyono. (2011). Metode Penelitian Bisnis, Bandung: Alfabeta, 2011.

Sya'idah, Evi Husniati, Tontowi Jauhari. (2018). Pengaruh Marketing mix Terhadap Loyalitas Pelanggan. Jurnal Ekonomi Universitas Kediri Volume 3 No.1.

Syahputra, Danil. (2019). Pengaruh Biaya Promosi dan Tingkat Margin terhadap Peningkatan Penyaluran Dana Pembiayaan Murabahah. Jurnal Penelitian Medan Agama Vol. 10, No. 1.

Umar, Husein. (2003). Riset Pemasaran dan Perilaku Konsumen. jakarta: Gramedia Pustaka Utama.

Wahab, Norsyaheera Abdul, Lailatul Faizah Abu Hassan, Siti Asiah Md Shahid, Siti Noorsuriani Maon. (2016). The Relationship Between Marketing mix and Customer Loyalty In Hijab Industry : The Mediating Effect of Customer Satisfaction. Procedia Economics and Finance 37. 366-371.

Wahab, Sulaiman. (2012). Perbandingan Marketing mix dan Faktor Religi Terhadap Keputusan Konsumen Menjadi Nasabah Bank Syariah. Jurnal Manajemen dan Akuntansi Volume 2 Nomor 2 Tahun 2013 Magelang. 
Winardi. (1989). Aspek-Aspek Marketing mix. Bandung: Mandar maju Yeu, Chan S, Kong C Leong, Lee C Tong, et al. (2012). A Comparative Study on International Marketing mix in China and India : The Case of McDonald's. Procedia-Social and Behavioral Sciences 65 1054-1059. 